\title{
Hak dan Kewajiban Untuk Mempertahankan Serta Meningkatkan Kualitas Kesehatan Masyarakat Melalui PHBS
}

\author{
Rossa Widhiya Ningrum \\ Institut Ilmu Kesehatan STRADA Indonesia
}

Lacitaivana717@gmail.com

\begin{abstract}
Abstrak
Pembangunan bidang kesehatan pada dasarnya ditujukan untuk meningkatkan kesadaran, kemauan dan kemampuan hidup sehat bagi setiap orang untuk mewujudkan derajat kesehatan yang optimal sebagai salah satu unsur kesejahteraan sebagaimana diamanatkan oleh pembukaan Undang-Undang Dasar Republik Indonesia 1945. Kondisi umum kesehatan Indonesia dipengaruhi oleh faktor lingkungan, perilaku, dan pelayanan kesehatan. Keberhasilan pembangunan kesehatan sangat ditentukan oleh kesinambungan antar upaya program dan sektor, serta kesinambungan dengan upaya-upaya yang telah dilaksanakan dalam periode sebelumnya. Kualitas kesehatan merupakan tingkat baik dan buruknya keadaan dari badan maupun jiwa. Untuk meningkatkan kualitas kesehatan bisa dilakukan dengan melaksanakan PHBS (Pola Hidup Bersih dan Sehat). Tujuan utama dari gerakan PHBS adalah meningkatkan kualitas kesehatan melalui proses penyadartahuan yang menjadi awal dari kontribusi individu - individu dalam menjalani perilaku kehidupan sehari - hari yang bersih dan sehat
\end{abstract}

Kata Kunci : Hak dan Kewajiban, Kualitas Kesehatan, PHBS

\section{Latar Belakang}

Pembangunan bidang

kesehatan pada dasarnya ditujukan untuk meningkatkan kesadaran, kemauan dan kemampuan hidup sehat bagi setiap orang untuk mewujudkan derajat kesehatan yang optimal sebagai salah satu unsur kesejahteraan sebagaimana diamanatkan oleh pembukaan Undang-Undang Dasar Republik
Indonesia 1945. Kesehatan sebagai hak asasi manusia (HAM) harus diwujudkan dalam bentuk pemberian berbagai upaya kesehatan kepada seluruh masyarakat melalui penyelenggaraan pembangunan kesehatan yang berkualitas dan terjangkau oleh masyarakat.

Kesehatan adalah salah satu kebutuhan dasar manusia. Begitu pentingnya, sehingga sering 
dikatakan bahwa kesehatan adalah segala-galanya, tanpa kesehatan segala-galanya tidak bermakna. Oleh karena itu, setiap kegiatan dan upaya untuk meningkatkan derajat kesehatan masyarakat yang setinggitingginya dilaksanakan berdasarkan prinsip nondiskriminatif, partisipatif, perlindungan, dan berkelanjutan yang sangat penting artinya bagi pembentukan sumber daya manusia Indonesia, peningkatan ketahanan dan daya saing bangsa, serta pembangunan nasional.

Kondisi umum kesehatan Indonesia dipengaruhi oleh faktor lingkungan, perilaku, dan pelayanan kesehatan. Sementara itu pelayanan kesehatan terdiri dari beberapa komponen antara lain ketersediaan dan mutu fasilitas pelayanan kesehatan, obat dan perbekalan kesehatan, tenaga kesehatan, pembiayaan dan manajemen kesehatan. Fasilitas pelayanan kesehatan dasar, yaitu Puskesmas yang diperkuat dengan Puskesmas Pembantu dan Puskesmas Keliling, telah didirikan di hampir seluruh wilayah Indonesia, namun pemerataan dan keterjangkauan pelayanan kesehatan masih menjadi kendala.

Kualitas atau mutu adalah tingkat baik buruknya atau taraf atau derajat sesuatu. Sedangkan kesehatan merupakan keadaan sejahtera dari badan, jiwa, dan sosial yang memungkinkan setiap orang hidup produktif secara sosial dan ekonomis. Sehingga dapat disimpulkan bahwa kualitas kesehatan merupakan tingkat baik dan buruknya keadaan dari badan maupun jiwa.

\section{Kasus / Masalah}

Indonesia sebagai negara berkembang masih dihadapkan pada masalah rendahnya akses masyarakat terhadap pelayanan kesehatan yang berkualitas. Penyelenggaraan pelayanan kesehatan tidak mampu menjawab kompleksitas penyelenggaraan dan pembiayaan pelayanan kesehatan yang semakin tergantung pada teknologi kesehatan yang semakin mahal dan rumit. Sistem pelayanan kesehatan yang padat teknologi dan semakin mahal menuntut penanganan yang profesional yang diselenggarakan oleh institusi yang handal dan menuntut metoda penyelenggaraan yang mampu bekerja efektif, efisien, dan sekaligus memuaskan. Oleh karena itu setiap individu memiliki hak dan kewajiban dibidang kesehatan terkait kualitas lingkungan yang sehat.

\section{Tinjauan Pustaka}

Kesehatan

merupakan kebutuhan dasar setiap manusia, untuk itu pemerintah mewujudkan pelaksanaan hak asasi manusia dibidang kesehatan tersebut dengan menetapkan Undang-Undang Nomor 36 Tahun 2009 tentang kesehatan. Kesehatan merupakan investasi 
untuk

mendukung

pembangunan ekonomi serta memiliki peran penting dalam upaya penanggulangan kemiskinan. Pembangunan kesehatan harus dipandang sebagai suatu investasi untuk meningkatkan kualitas sumber daya manusia sesuai dengan Undang-Undang Nomor 36 Tahun 2009 tentang Kesehatan.

Pembangunan kesehatan pada hakekatnya adalah upaya yang dilaksanakan oleh semua komponen bangsa Indonesia yang bertujuan untuk meningkatkan kesadaran, kemauan, dan kemampuan hidup sehat bagi setiap orang agar terwujud derajat kesehatan masyarakat yang setinggi-tingginya. Keberhasilan pembangunan kesehatan sangat ditentukan oleh kesinambungan antar-upaya program dan sektor, serta kesinambungan dengan upaya-upaya yang telah dilaksanakan dalam periode sebelumnya.

Perilaku kesehatan

merupakan segala aktivitas atau kegiatan seseorang, baik yang dapat diamati secara langsung (observable) maupun yang tidak dapat diamati secara langsung oleh orang lain (unobservable) yang berkaitan dengan pemeliharaan dan peningkatan kesehatan. Oleh sebab itu perilaku kesehatan ini pada garis besarnya dikelompokkan menjadi dua, yakni : perilaku sehat (Health
Behavior) yang merupakan perilaku orang yang sehat agar tetap sehat atau kesehatannya meningkat dan perilaku pencarian kesehatan (Health Seeking Behavior) yang merupakan perilaku orang yang sakit atau telah terkena masalah kesehatan untuk memperoleh penyembuhan atau pemecahan masalah kesehatannya.

Berdasarkan teori dasar yang dikembangkan oleh Lawrence Green (1991) dalam Nursalam (2014:80), kesehatan seseorang atau masyarakat dipengaruhi oleh dua faktor pokok yaitu faktor perilaku (behavior causes) dan faktor diluar perilaku (non-behavior causes). Sementara faktor perilaku (behavior causes) dipengaruhi oleh tiga faktor yakni : faktor predisposisi (Predisposing Factors) yang meliputi umur, pekerjaan, pendidikan, pengetahuan dan sikap, faktor pemungkin (Enabling Factors) yang terwujud dalam lingkungan fisik dan jarak ke fasilitas kesehatan, dan faktor penguat (Reinforcing Factors) yang terwujud dalam dukungan yang diberikan oleh keluarga maupun tokoh masyarakat (Notoatmodjo, 2014:76).

Kualitas kesehatan merupakan tingkat baik dan buruknya keadaan dari badan maupun jiwa. Untuk meningkatkan kualitas kesehatan bisa dilakukan dengan melaksanakan PHBS (Pola Hidup Bersih dan Sehat). Pengertian PHBS adalah semua perilaku kesehatan yang dilakukan karena 
kesadaran pribadi sehingga keluarga dan seluruh anggotanya mampu menolong diri sendiri pada bidang kesehatan serta memiliki peran aktif dalam aktivitas masyarakat.

Perilaku Hidup Bersih dan Sehat pada dasarnya merupakan sebuah upaya untuk menularkan pengalaman mengenai perilaku hidup sehat melalui individu, kelompok ataupun masyarakat luas dengan jalur - jalur komunikasi sebagai media berbagi informasi. Ada berbagai informasi yang dapat dibagikan seperti materi edukasi guna menambah pengetahuan serta meningkatkan sikap dan perilaku terkait cara hidup yang bersih dan sehat.

\section{Pembahasan}

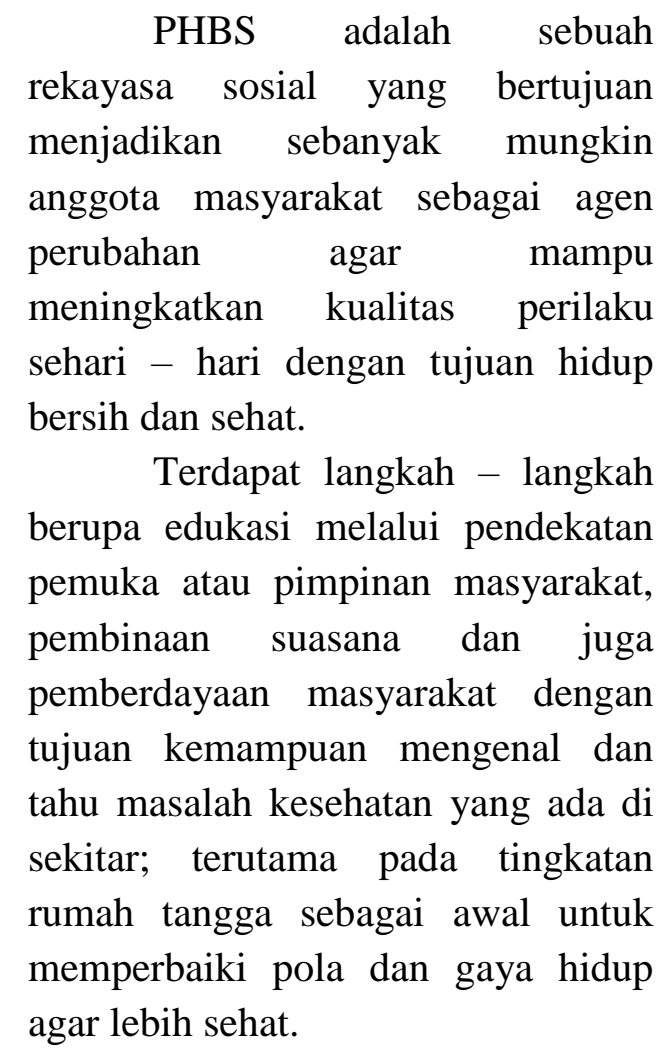

Tujuan utama dari gerakan PHBS adalah meningkatkan kualitas kesehatan melalui proses penyadartahuan yang menjadi awal dari kontribusi individu - individu dalam menjalani perilaku kehidupan sehari - hari yang bersih dan sehat. Manfaat PHBS yang paling utama adalah terciptanya masyarakat yang sadar kesehatan dan memiliki bekal pengetahuan dan kesadaran untuk menjalani perilaku hidup yang menjaga kebersihan dan memenuhi standar kesehatan.

Tatanan PHBS melibatkan beberapa elemen yang merupakan bagian dari tempat beraktivitas dalam kehidupan sehari - hari. Berikut ini 5 tatanan PBHS yang dapat menjadi simpul - simpul untuk memulai proses penyadartahuan tentang perilaku hidup bersih sehat :

1. PHBS di Sekolah

2. PHBS di Rumah tangga

3. PHBS di Tempat kerja

4. PHBS di Sarana kesehatan

5. PHBS di Tempat umum

Manfaat PHBS secara umum adalah meningkatkan kesadaran masyarakat untuk mau menjalankan hidup bersih dan sehat. Hal tersebut agar masyarakat bisa mencegah dan menanggulangi masalah kesehatan. Selain itu, dengan menerapkan PHBS masyarakat mampu menciptakan lingkungan yang sehat dan meningkatkan kualitas hidup.

\section{a. Manfaat PHBS di Sekolah}


PHBS di sekolah merupakan kegiatan memberdayakan siswa, guru dan masyarakat lingkungan sekolah untuk mau melakukan pola hidup sehat untuk menciptakan sekolah sehat. Manfaat PHBS di Sekolah mampu menciptakan lingkungan yang bersih dan sehat, meningkatkan proses belajar mengajar dan para siswa, guru hingga masyarakat lingkungan sekolah menjadi sehat.

b. Manfaat PHBS di Rumah Tangga

Menerapkan PHBS di rumah tangga tentu akan menciptakan keluarga sehat dan mampu meminimalisir masalah kesehatan. Manfaat PHBS di rumah tangga antara lain, setiap anggota keluarga mampu meningkatkan kesejahteraan dan tidak mudah terkena penyakit, rumah tangga sehat mampu meningkatkan produktivitas anggota rumah tangga dan manfaat PHBS rumah tangga selanjutnya adalah anggota keluarga terbiasa untuk menerapkan pola hidup sehat dan anak dapat tumbuh sehat dan tercukupi gizi.

c. Manfaat PHBS di Tempat Kerja

PHBS di Tempat kerja adalah kegiatan untuk memberdayakan para pekerja agar tahu dan mau untuk melakukan Perilaku Hidup Bersih dan Sehat dan berperan dalam menciptakan tempat kerja yang sehat. manfaat PHBS di tempat kerja yaitu para pekerja mampu meningkatkan kesehatannya dan tidak mudah sakit, meningkatkan produktivitas kerja dan meningkatkan citra tempat kerja yang positif.

d. Manfaat PHBS di Masyarakat

Manfaat PHBS di masyarakat adalah masyarakat mampu menciptakan lingkungan yang sehat, mencegah penyebaran penyakit, masyarakat memanfaatkan pelayanan fasilitas kesehatan dan mampu mengembangkan kesehatan yang bersumber dari masyarakat.

Pentingnya PHBS di setiap tatanan. Keseluruhan dari materi PHBS bertujuan untuk meningkatkan kualitas kesehatan individu dan masyarakat yang terlibat pada setiap tatanan. Sekolah yang sehat dengan anggota komunitas tingkat sekolah yang berperilaku Hidup Bersih dan Sehat dapat mencegah sekolah menjadi titik penularan atau sumber berbagai penyakit. Demikian pula dengan PHBS di tempat kerja dimana keamanan dan kesehatan menjadi sesuatu yang tidak kalah penting.

Perilaku Hidup Bersih dan Sehat yang berasal dari implementasi materi PHBS dapat menjadi kunci untuk meningkatkan kualitas 
kesehatan masyarakat. Menjalankan praktek indikator - indikator PHBS di berbagai tatanan dapat menjadi sebuah gerakan untuk memasyarakatkan Perilaku Hidup Bersih dan Sehat dimanapun dan juga kapanpun.

Tujuan dari pembangunan kesehatan adalah untuk meningkatkan kesadaran, kemauan, dan kemampuan hidup sehat bagi setiap orang agar terwujud derajat kesehatan masyarakat yang setingitingginya, sebagai investasi bagi pembangunan sumber daya manusia yang produktif secara sosial dan ekonomis, sebagaimana ditegaskan dalam ketentuan Pasal 3 UndangUndang Nomor 36 Tahun 2009 tentang Kesehatan. Untuk mencapai tujuan pembangunan kesehatan, maka setiap individu mempunyai hak dan kewajiban. Hak dan Kewajiban individu dibidang kesehatan untuk mempertahankan dan meningkatkan derajat kesehatan ialah :

\section{a. Hak}

- Mempunyai hak yang sama dalam memperoleh akses atas sumber daya dibidang kesehatan

- Berhak mendapatkan lingkungan yang sehat bagi pencapaian derajat kesehatan.

- Berhak mendapatkan informasi dan edukasi tentang kesehatan yang seimbang dan bertanggung jawab

\section{b. Kewajiban}

- Berkewajiban ikut mewujudkan, mempertahankan, dan meningkatkan derajat kesehatan masyarakat yang setinggi-tingginya, yang meliputi kesehatan perseorangan, upaya kesehatan masyarakat, dan pembangunan berwawasan kesehatan.

- Berkewajiban menghormati hak orang lain dalam upaya memperoleh lingkungan yang sehat, baik secara fisik, biologi, maupun sosial.

- Berkewajiban berperilaku hidup sehat untuk mewujudkan, mempertahankan, dan memajukan kesehatan yang setinggi-tingginya.

- Berkewajiban menjaga dan meningkatkan derajat kesehatan bagi orang lain yang menjadi tanggung jawabnya.

\section{Kesimpulan}

Agar terselenggaranya PHBS (Pola Hidup Bersih dan Sehat) sangat diperlukam kesadaran masyarakat untuk menerapkannya dalam kehidupan seharihari secara berkelanjutan agar dapat meningkatkan derajat kesehatan masyarakat. Selain itu antara hak dan kewajiban masyarakat terkait kualitas kesehatan masyarakat harus berjalan secara seimbang. Ketika masyarakat berkewajiban mempertahankan dan 
meningkatkan kesehatan yang setinggitingginya dengan dimulai dari kesehatan perseorangan, maka masyarakat pun berhak mendapatkan lingkungan yang sehat bagi pencapaian derajat kesehatan.

\section{Daftar Pustaka}

Hidajaturrokhmah, N. Y., Nurikasari, M., Retnaningtyas, E., Siwi, R. P. Y., Sari, N., \& Sodik, M. A. (2018). Effectiveness of health education using audio visual with lectures and poster with lectures of changes in behavior selection of snacks. Indian Journal of Physiotherapy and Occupational Therapy-An International Journal, 12(4), 220-224.

Sodik, M. A., \& Setyani, A. T. (2018). Effect of Smoking For Teens Against Behavior and Social Interaction.

Sodik, M. A., \& Nzilibili, S. M. M. (2017). The Role Of Health Promotion And Family Support With Attitude Of Couples Childbearing Age In Following Family Planning Program In Health. Journal of Global Research in Public Health, 2(2), 82-89.

Hafid Abbas, et.el., Buku Pedoman Hak Asasi Manusia bagi Dokter dan Pasien Dalam Mencegah Malapraktek Kedokteran, Badan Penelitian dan Pengembangan HAM Departemen Hukum dan HAM RI, 2008., hlm. 1

Indra Perwira, Kesehatan Sebagai Hak Asasi Manusia, dalam Bagir Manan, et.al., Dimensi-Dimensi Hukum Hak Asasi Manusia, PSKN FH UNPAD, Bandung, 2009., hlm. 138

Jurnal Ilmu Hukum Opinion Edisi 2, Volume 3, Tahun 2015

Sulastomo, Substansi dan Filosofi UU Nomor 40 Tahun 2004 Tentang SJSN, Rakernas SJSN dan Jaminan Sosial Kesehatan, Menkokesra, 15-16 Maret, 2006. 